\title{
ビンガム流体の跳水およでダム越流流れの 水理学的特性
}

\section{荻原能男* ·宮沢直季**}

本研究では，展方抢断画開水路においてビンガム流体とみなせる水とベントナイトの 混合流体を用いて不等流実駼を行い，ダム越流による流机および跳水が混合流体の浱度 によってどのように変化するかを考察した。 その絬果, 浱度が $2.6 \%$ 以下 (降伏応力 $\tau_{f}<0.38 \mathrm{~Pa}$, 塑性籼度 $\left.\eta_{p l}<23 \mathrm{mPa} \cdot \mathrm{s}\right)$ の混含流体に対して, 実駼值は従来の跳水に 崩する公式をほぼ満足することがボされた。また，体䅡浱度が $3.0 \%$ を越えると $\left(\tau_{f}>\right.$ $\left.1.2 \mathrm{~Pa}, \eta_{p l}>46 \mathrm{mPa} \cdot \mathrm{s}\right)$, 限界水深は念激に人きくなること, 浱度が $4.0 \%\left(\tau_{f}=19 \mathrm{~Pa}\right.$, $\eta_{p l}=364 \mathrm{mPa} \cdot \mathrm{s}$ ) のときに限界水深の約 $10 \%$ が栓流であることが拉された.

Key Words : flow over a dam, hydraulic jump, critical depth, specfic force, Bingham fluid, rectangular open channel

\section{1. 序論}

梅雨や豪雨なざの際に甚大な被害をもたらす泥流，土 石流に関しては, その防災上様々な研究が行われている. これらの研究を進めていく上で, まず泥流, 土石流をよ゙ のような流体モデルに仮定するかが重要である．高橋1 は砂を用いた堆積層上の土石流の流れがダイラタント流 体として扱い得ることを確かめた。また谷口”1は粘土を 用いた泥水の実験から流れがビンガム流体として扱い得 ることを示している.

施工現場での流動化コンクリートの開水路流れ等の問 題に関しても研究が必要になっている.

本研究は前述の泥流，土石流，流動化コンクリートな ビの非ニュートン流体の流動特性を解明するための基礎 的研究として非ニュートン流体の代表的モデルであるビ ンガム流体の開水路における流動特性を明らかにするこ とを目的としている.

ビンガム流体の開水路流れは水に代表されるニュート ン流体の流れと全く異なることが予想される. 従来, 山 岡ら ${ }^{31}$ の流路工内を流れる泥流の平均流速に関する実験 や Hao ら"の長方形断面開水路の泥水の抵抗実験など主 として等流状態を対象とした研究が行われ, 多くの知見 が得られているが, 本研究で対象とするダム越流による 流れや跳水については泥流, 土石流の流路工などの設計 において重要であるにも関わらずほとんど研究されてい ない.ささらに限界水深が明らかにされなけ机ば水面形を 知ることが出来ない.

本研究では, 長方形断面開水路にダム模型を取り付け て, 水とベントナイトの混合流体を用いて開水路の不等 流実験を実施し, 濃度の違いによるダム越流による流れ

\footnotetext{
*正会員 工博 山梨大学教授 工学部土木環境工学科 ( 于400 山梨県甲府市武田 4-3-11)

**正会員 工修 山梨大学助手工学部土木環境工学科
}

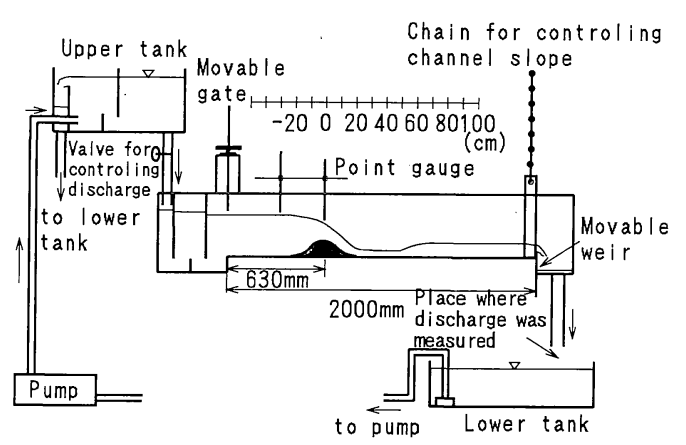

図-1 開水路の不等流実験装置

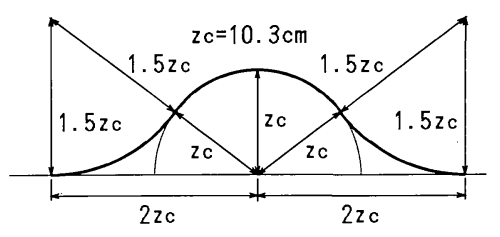

図一2 ダム模型の形状

の変化を考察する.さらにダム下流に跳水を発生させて, 跳水が濃度によってどのように変化するかを考察するこ とを目的とする。

\section{2. 開水路の不等流実験}

実験装置を図一1 に示す，この図のように混合流体は ポンプによって高水槽に上げられ, そこから開水路へ流 れ出し, 低水槽に戻り, 再びポンプで吸い上げられ循環 する. 開水路は水路幅 $B=10 \mathrm{~cm}$, 長さ $2.0 \mathrm{~m}$ の長方形 断面で, 側壁, 水路底とも透明な塩化ビニール製である. なお，水路は水平である．この水路に図一2のような形 状のダム模型を水路入口から $63 \mathrm{~cm}$ の場所に取り付け た. ダム模型は鋼鉄製で, その高さは $z_{c}=10.3 \mathrm{~cm}$ であ る. また, ダム下流に跳水を発生させるために下流端に 

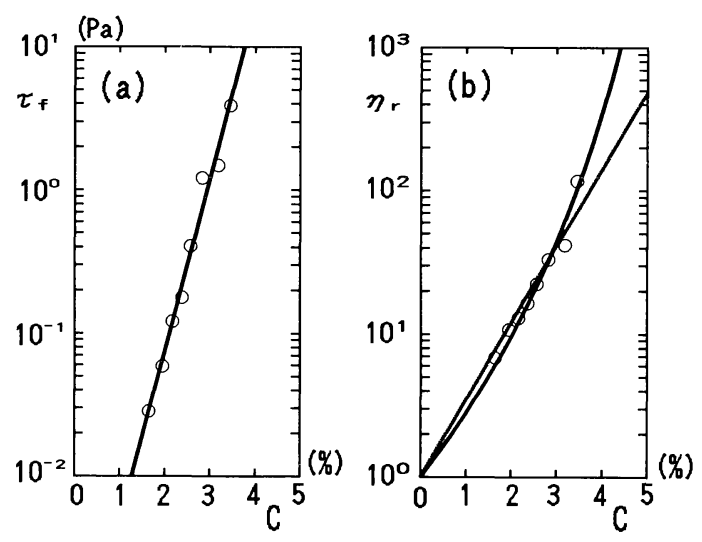

図一3 （a）体積濃度 $C$ と降伏応力 $\tau_{f}$ の関係，（b）体積濃度 $C$ と相対粘度 $\eta_{r}$ の関係

可動せきを取り付け，ダム頂の位置から下流側約 $50 \mathrm{~cm}$ の位置に跳水の先頭がくるように下流端のせきの高さを 調整した。

実験で用いた液体は水とベントナイトの混合流体であ り，この流体がビンガム流体とみなせることは著者らの 管路の抵抗実験 ${ }^{5}$ により確認されている. ベントナイト はクニミネ工業 (株) 製のベントナイト精製粉末 (クニ ゲルーVA）を使い，その固形部分の比重は比重試験に よって 2.571 であった，実験で用いた水とベントナイト の混合流体の体積濃度 $C$ 上降伏応力 $\tau_{f}$ の関係を図一3

（a）に示す. 同図には次の回帰式を実線で示した.

$\log \tau_{f}=1.20 C-3.53$

\section{$\left(C\right.$ in $\%, \tau_{f}$ in $\left.\mathrm{Pa}\right)$}

また，図一3（b ）に体積濃度 $C$ と相対粘度 $\eta_{r}$ （=混合 流体の塑性粘度 $\eta_{p l} /$ 水の粘性係数 $\mu$, この実験では $\mu=$ $1.04 \mathrm{mPa} \cdot \mathrm{s}$ ) の関係を示す. 同図に次の回帰式を示した.

$$
\begin{aligned}
& \eta_{r}=(1-C / 6.43)^{-6.02} \text { (実線) } \\
& \log \eta_{r}=0.537 C \text { (点線) }
\end{aligned}
$$

$$
\text { ( } C \text { in \%) }
$$

濃度の増加とともに降伏応力と塑性粘度は指数関数的に 増加する。

流量 $Q$ を重量法によって測定した．開水路に混合流 体が流れているときのダムの上流側，下流側から試料を 採取してその体積濃度を決めた。ダム頂地点から上流側 $30 \mathrm{~cm}$ の地点とダム頂上で水深をポイントゲージで測定 した。また，水路壁に OHP 用紙を貼り水面形を記入し た. 以上のことを流量と濃度を変えて繰り返し行った。

\section{3. 実験結果および考察}

\section{（1）不等流実験結果}

水路全体の流れの様子が混合流体の濃度によってビの ように変化するかを考察する。図一4に流量が約 1200

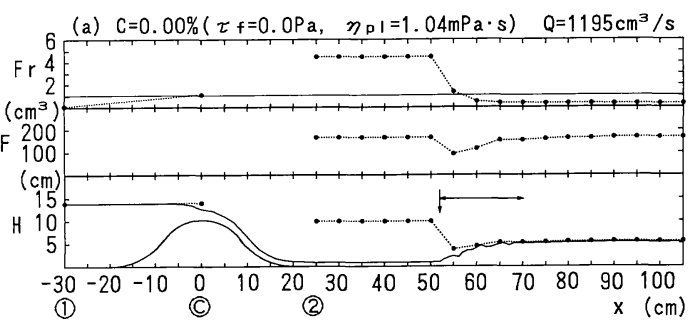

(b) $\mathrm{C}=1.71 \%\left(\tau_{\mathrm{f}}=0.033 \mathrm{~Pa}, \quad \eta_{\mathrm{pl}}=6.68 \mathrm{mPa} \cdot \mathrm{s}\right) \quad \mathrm{Q}=1190 \mathrm{~cm}^{3} / \mathrm{s}$

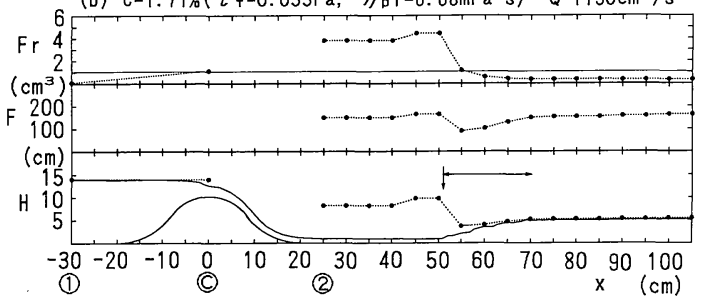

(c) $\mathrm{C}=2.59 \%\left(\tau \mathrm{f}=0.378 \mathrm{~Pa}, \quad \eta_{\mathrm{pl}}=23.1 \mathrm{mPa} \cdot \mathrm{s}\right) \quad Q=1218 \mathrm{~cm}^{3} / \mathrm{s}$

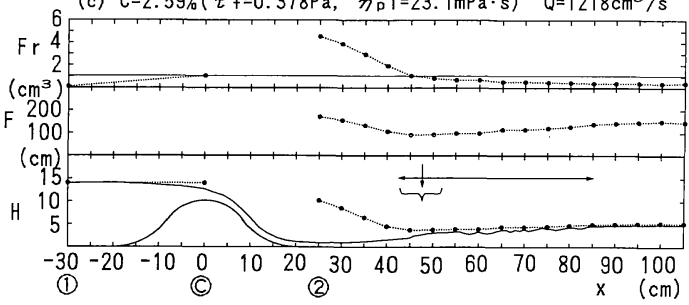

(d) $C=3.85 \%\left(\tau f=12.3 \mathrm{~Pa}, \quad \eta_{\mathrm{D}}=253 \mathrm{mPa} \cdot \mathrm{s}\right) \quad Q=1234 \mathrm{~cm}^{3} / \mathrm{s}$

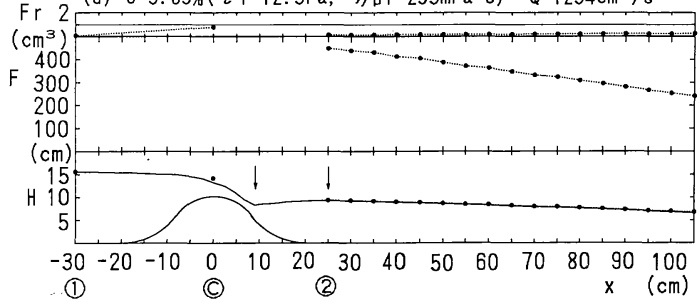

図一4 水面形, 全水頭 $H$, 比力 $F$, フルード数 $F_{r}$ の実験結果

$\mathrm{cm}^{3} / \mathrm{s}$ の場合の水面形および全水頭 $H$, 比力 $F$, フルー ド数 $F_{r}$ の流下方向の変化を体積濃度別に示す. 全水頭 の基準面は水路床に取っている. 全水頭, 比力およびフ ルード数は次式から計算した。

$$
\begin{aligned}
& \text { 全水頭 } H=\frac{\alpha Q^{2}}{2 g B^{2} h^{2}}+h+z, \alpha=1 \cdots \cdots \\
& \text { 比力 } F=\frac{\beta Q^{2}}{g B h}+\frac{1}{2} \gamma B h^{2}, \beta=1, \gamma=1 \\
& \text { フルード数 } F_{r}=\sqrt{\frac{\alpha}{g h}} \cdot V \quad \alpha=1 \cdots \cdots
\end{aligned}
$$

ここに, $\alpha$ : エネルギー係数, $g$ : 重力加速度, $h:$ 水深, $z$ : 基準面から水路床までの高さ, $\beta$ : 運動量係数, $\gamma$ : 圧力係数, $V$ : 断面平均流速である. 工ネルギー係数 $\alpha$ は場所によって変化し, 後述するように体積濃度によっ ても変化すると考えられる.ここでは水路全体の流れの 


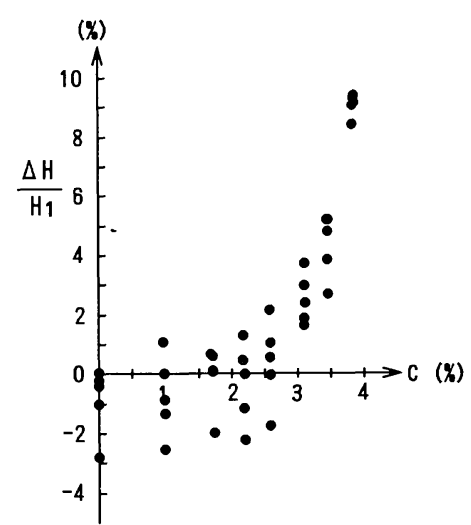

図一5 濃度 $C$ に対するエネルギー損失 $\Delta H$ の変化

状態をみるために通常使われている $\alpha=1$ とした. 図一

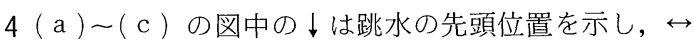
は跳水区間を示す，先頭位置および跳水区間は流れの観 測から決定されたものである.

体積濃度が $0.00 \%$ の場合（水の場合）では， $x=$ $-30 \mathrm{~cm}$ の断面 (以後断面(1)と呼ぶ) の全水頭は $x=0$ $\mathrm{cm}$ の断面 (以後断面(C)上呼ぶ) の全水頭に等しい. し かし， $x=25 \mathrm{~cm}$ の断面 (以後断面(2)と呼ぶ) の全水頭 は断面(1), (C)の全水頭に比べて小さい. 理論的には全水 頭は等しくなるはずであるが，断面(2)までに壁面摩擦に よって流れのエネルギーが多少損失されている，一方， 跳水前後ではエネルギーは損失されているが，比力は等 しい. 図一4( b ) のような濃度が小さい場合 $(C=1.71 \%)$ の流れの様子は水の場合の図一4( a ) と同じ傾向を示す.

図一4（c）の体積濃度が 2.59\% の場合には，断面(1) と断面(C)で全水頭はほぼ等しい。しかし射流領域では, 濃度が小さい場合亡比べて水深は一定でなく徐々に増加 し，流れのエネルギーは損失される.これは水路に沿う 壁面摩擦によるエネルギー損失が低濃度の場合に比べて 大きいことによる. また, 跳水の先頭位置は明瞭でなく, 跳水後水面の動摇が下流方向に続いていることが観測さ れた。従って, 跳水長は濃度の小さい場合上りも長くな る.

図一4（d）に体積濃度が $3.85 \%$ の場合を示す．図中 の】は一方がせき上げた液体がダムに当たっている地 点, もう一方が水深が最も深い地点を示す. この場合, 断面(1)から断面(C)かけてエネルギー損失がある.ダム を越えた後で比力 $F$ は濃度の小さい場合と比べて非常 に大きな值を示す．また，フルード数 $F_{r}$ を見るとダム 越流後完全に常流になっている. 水面形はダムを越えて その流体が溜まっているように水深が増加し, 再び下 がっているようなニュートン流体には見られない特異な 形状を示す.

次に，断面(1)と断面Cでよ゙のくらいのエネルギー損失

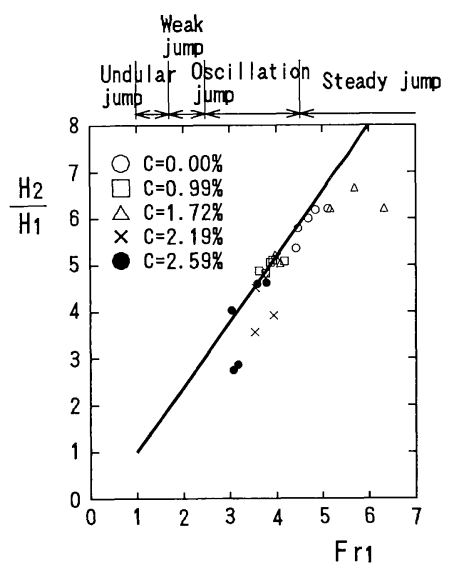

図一6 水平な長方形断面水路における跳水に対する $F_{r 1}$ と $H_{2}$ $/ H_{1}$ との関係

があるか考察する. 図一5に断面(1)の全水頭と断面(C) 全水頭の差 $\Delta H$ の体積濃度による変化を示す. 体積濃度 が $0 \%$ の場合 (水の場合), 水深, 流量の測定誤差によっ てマイナスの值となっているが， $\Delta H$ はほとんどゼロで ある. また, 体積濃度が $3.0 \%$ までは $\Delta H$ はほとんどゼ ロである.しかし, 濃度が $3.0 \%$ を越えるとエネルギー 損失が大きくなり，上流側（断面(1)）の全水頭 $H_{1}$ の約 $9 \%$ の竝ルギーが失われる.この体積濃度 $3.0 \%$ は後 述するように断面(C)で壁面せん断応力 $\tau_{0}$ に対する降 伏応力 $\tau_{f}$ の比が約 0.025 の場合に対応する.

\section{（2）跳 水}

水平な長方形断面水路において跳水前の水深 $H_{1}$, 跳 水後の水深 $H_{2}$ および跳水前のフルード数 $F_{r_{1}}=\frac{V_{1}}{\sqrt{g H_{1}}}$ が次式を満足するとき跳水が起こる. この式は跳水前後 で比力を等しくすることによって求められる.

$$
\frac{H_{2}}{H_{1}}=\frac{\sqrt{1+8 F r_{1}^{2}}-1}{2}
$$

この式は図一6の実線で表される.この図に実験值をプ ロットした．跳水前の水深 $H_{1}$ は跳水先頭より上流側地 点の水深を平均した值を用い, 跳水後の水深 $H_{2}$ は跳水 区間より下流側地点の水深を平均した值を用いた。この 図から混合流体の濃度が増しても式（7）の関係式を満 足することがわかる.

体積濃度が $1.72 \%$ 以下では図一 4 からわかるように 射流域のエネルギ一損失はほとんど見られず，壁面せん 断応力 $\tau_{0}$ は小さいと考えられる. 体積濃度が $2.19 \%$, $2.59 \%$ の場合の射流域の壁面せん断応力 $\tau_{0}$ を式 (11) を使って計算すると表一-1のようになる. 表中の括弧内 の数値は $\tau_{f} / \tau_{0}$ の計算值を示す. 従って, 射流域の栓流 厚は極めて小さく, 無視することが出来る. 一方, 跳水 後の常流域のエネルギー勾配は平均的な $1 / 400$ を用いて 体積濃度が $2.19 \% ， 2.59 \%$ の場合の常流域の壁面せん 断応力 $\tau_{0}$ を計算すると表一 2 のようになる.これより 
表一1 射流域の壁面せん断応力 $\tau_{0}$

\begin{tabular}{|c|c|c|c|}
\hline & \multicolumn{2}{|c|}{ 体積瀑度 $C$} \\
\hline & & $2.19 \%$ & 2. $59 \%$ \\
\hline 流 & $1478 \mathrm{~m}^{8} / \mathrm{s}$ & $16.3 N / m^{2}(0.008)$ & $35.6 \mathrm{~N} / \mathrm{m}^{2}(0.011)$ \\
\hline \multirow[t]{2}{*}{ 量 } & $1227 \mathrm{~m}^{8} / \mathrm{s}$ & $24.4 \mathrm{~N} / \mathrm{m}^{2}(0.005)$ & $36.0 \mathrm{~N} / \mathrm{m}^{2}(0.011)$ \\
\hline & $1012 \mathrm{~m}^{\mathrm{3}} / \mathrm{s}$ & $15.8 \mathrm{~N} / \mathrm{m}^{2}(0.008)$ & $52.9 \mathrm{~N} / \mathrm{m}^{2}(0.007)$ \\
\hline \multirow[t]{2}{*}{$Q$} & $848 \mathrm{~m}^{2} / \mathrm{s}$ & $12.6 \mathrm{~N} / \mathrm{m}^{2}(0.010)$ & $18.6 \mathrm{~N} / \mathrm{m}^{2}(0.020)$ \\
\hline & $702 \mathrm{~m}^{2} / \mathrm{s}$ & $27.0 \mathrm{~N} / \mathrm{m}^{2}(0.005)$ & $19.9 \mathrm{~N} / \mathrm{m}^{2}(0.019)$ \\
\hline \multicolumn{2}{|c|}{$\tau_{f}$} & $0.125 \mathrm{~N} / \mathrm{m}^{2}$ & $0.378 \mathrm{~N} / \mathrm{m}^{2}$ \\
\hline
\end{tabular}

表一2 常流域の壁面せん断応力 $\tau_{0}$

\begin{tabular}{|c|c|c|c|}
\hline & \multicolumn{2}{|c|}{ 体積漕度 $C$} \\
\hline & & $2.19 \%$ & 2. $59 \mathrm{x}$ \\
\hline 流 & $1478 \mathrm{~m}^{2} / \mathrm{s}$ & $0.69 \mathrm{~N} / \mathrm{m}^{2}(0.18)$ & $0.65 \mathrm{~N} / \mathrm{m}^{2}(0.58)$ \\
\hline \multirow[t]{2}{*}{ 量 } & $1227 \mathrm{~m}^{\mathrm{s}} / \mathrm{s}$ & $0.63 \mathrm{~N} / \mathrm{m}^{2}(0.20)$ & $0.62 \mathrm{~N} / \mathrm{m}^{2}(0.61)$ \\
\hline & $1012 \mathrm{~m}^{2} / \mathrm{s}$ & $0.58 \mathrm{~N} / \mathrm{m}^{2}(0.22)$ & $0.59 \mathrm{~N} / \mathrm{m}^{2}(0.64)$ \\
\hline \multirow[t]{2}{*}{$Q$} & $848 \mathrm{~m}^{2} / \mathrm{s}$ & $0.48 \mathrm{~N} / \mathrm{n}^{2}(0.26)$ & $0.43 \mathrm{~N} / \mathrm{m}^{2}(0.88)$ \\
\hline & $702 \mathrm{~m}^{3} / \mathrm{s}$ & $0.43 \mathrm{~N} / \mathrm{m}^{2}(0.29)$ & $0.40 \mathrm{~N} / \mathrm{m}^{2}(0.95)$ \\
\hline \multicolumn{2}{|c|}{$\tau_{f}$} & $0.125 \mathrm{~N} / \mathrm{m}^{2}$ & $0.378 \mathrm{~N} / \mathrm{m}^{2}$ \\
\hline
\end{tabular}

$\tau_{f} / \tau_{0}$ の值は大きく, 跳水後の栓流部の存在が認められ ると考えられる.

水平床に生じる跳水には，いくつかの異なった形式が あるが，跳水前のフルード数によって図一6のように分 類することが出来る ${ }^{6}$. 実験データはフルード数が $3 〜 7$ の範囲にあり，これによると振動跳水 (Oscillation Jump), 定常跳水 (Steady Jump) に分類される. 特に, 濃度の大きいデー夕は振動跳水であり, 上述の観測結果 と対応する.

跳水後の比エネルギー $E_{2}$ 上跳水前の比エネルギー $E_{1}$ との比は次式で表される.

$$
\frac{E_{2}}{E_{1}}=\frac{\left(8 F_{r 1}^{2}+1\right)^{3 / 2}-4 F_{r 1}^{2}+1}{8 F_{r 1}^{2}\left(2+F_{r 1}^{2}\right)}
$$

この式を図示すると図一7のようになる．図の右の縦軸 は跳水前の比エネルギー $E_{1}$ に対する跳水のエネルギー 損失 $\left(E_{1}-E_{2}\right)$ を表す。この図に実験値をプロットす ると，実験值は式（8）の理論曲線を满足する.

跳水の高さ $H_{j}=H_{2}-H_{1}$ と比エネルギー $E_{1}$ との比は 次式で表される.

$$
\frac{H_{j}}{E_{1}}=\frac{\sqrt{1+8 F_{r 1}^{2}}-3}{F_{r 1}^{2}+2}
$$

この式は図一8に実線で表される。この図に実験值を プロットすると, 実験値は式（9）の理論曲線を満足す る.

跳水の長さはその先端部の曲面からローラーのすぐ下 流の水面上の点までの距離と定義されるが，それを理論 的に決定することは難しく, 多くの実験的研究が行われ

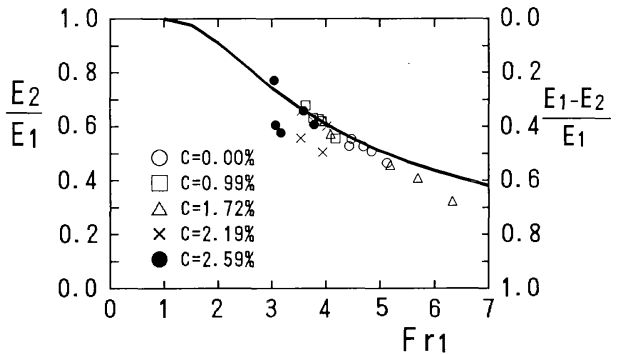

図一7 水平な長方形断面水路における跳水のエネルギー損失 $\left(E_{1}-E_{2}\right) / E_{1}$

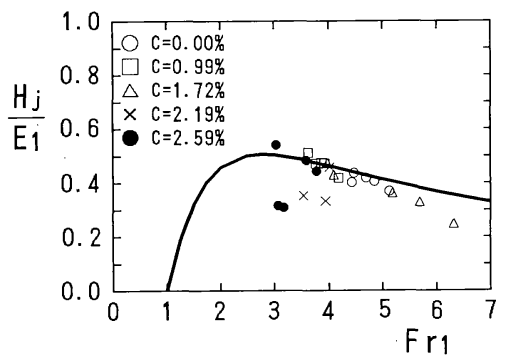

図一8 水平な長方形断面水路における跳水の高さ $H_{j} / E_{1}$

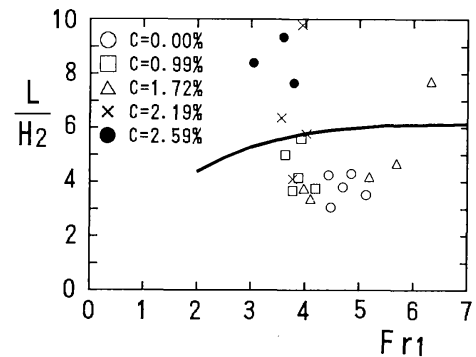

図一9 水平水路の跳水長 $L$ 之跳水前のフルード数 $F_{r 1}$ 亡の関係

ている. 図一9に示した曲線はU.S. Bureau of Reclamation の実験 ${ }^{1}$ による跳水長である. 本実験で得ら れた跳水長の值は観測によって得られたものであるの で, 実験データのばらつきは大きいが, これによると濃 度の小さいデータの跳水長は Bureau of Reclamationの 跳水長よりも小さく，濃度の大きいデー夕はそれよりも 大きいことがわかる．濃度の大きい場合は跳水後に水面 の動摇が大きく, 従って濃度の小さい場合よりも跳水長 が長くなる。

\section{（3）公么付近の栓流の様子}

ビンガム流体特有の栓流がダム付近の流れによってぼ のように変化するかを考察する．図一10に体積濃度が $3.83 \%\left(\tau_{f}=12 \mathrm{~Pa}, \eta_{p l}=242 \mathrm{mPa} \cdot \mathrm{s}\right)$, 流量が $986 \mathrm{~cm}^{3} / \mathrm{s}$ の場合のダム付近の流れの様子を示す。 $\triangle$ が全水頭の高 さ，実線がエネルギー線，○が水面の高さの実験值を表 す。また，○は栓流の高さを表し，水面との差が栓流厚 $h_{f}$ を表す. ダム付近でせん断応力がゼのように分布し 

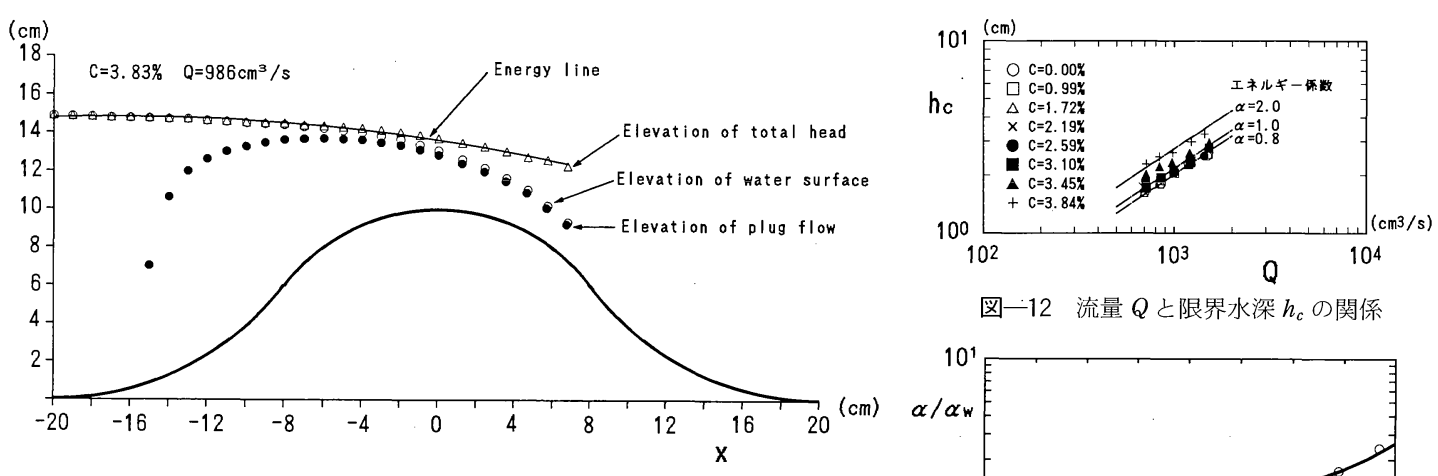

図-12 流量 $Q$ 亡限界水深 $h_{c}$ の関係

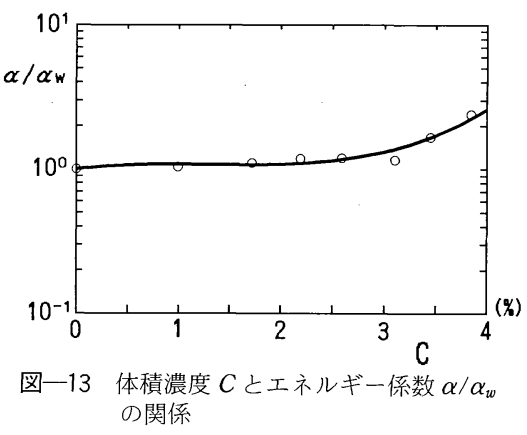

する. 図一12 に流量 $Q$ とダム頂上での水深，すなわち 限界水深 $h_{c}$ の測定値を両対数グラフにプロットした. 体積濃度が $3.0 \%$ を越えると，すなわち $\tau_{f} / \tau_{0}>0.025$ のときに限界水深は急激に大きくなることがわかる．長 方形断面水路における限界水深亡流量の理論的関係

$$
h_{c}=\sqrt[3]{\alpha Q^{2} / g B^{2}}
$$

より限界水深は流量の $2 / 3$ 乗に比例する. 従って, 両対 数グラフにプロットすると勾配 $2 / 3$ の直線になる. 実験 結果によると, 流量 $Q$ と限界水深 $h_{c}$ の関係はどの濃度 $C$ に対してもほぼ勾配 $2 / 3$ の直線にのる. 濃度 $C$ が増 加すると限界水深 $h_{c}$ が増加するのは, 式 (12) の関係 からダム頂地点（限界水深の地点）のエネルギ一係数 $\alpha$ が濃度によって変化することによると考えられる。

図一13に体積濃度 $C$ 亡体積濃度が $0.0 \%$ の場合の工 ネルギー係数 $\alpha_{w}$ に対する各濃度のエネルギー係数 $\alpha$ の 比 $\alpha / \alpha_{w}$ の関係を示す. 体積濃度が $3.0 \%\left(\tau_{f}=1.2 \mathrm{~Pa}\right.$, $\left.\eta_{p l}=46 \mathrm{mPa} \cdot \mathrm{s}\right)$ までは $\alpha / \alpha_{w}$ の值はほぼ 1 に等しいが, $3.0 \%$ を越えると増加する. 同図に次式の回帰式を実線 で示した。なお，この回帰式の適用範囲は $C<3.8 \%$, すなわち $\tau_{f} / \tau_{0}<0.094$ である.

$$
\log \left(\alpha / \alpha_{w}\right)=0.091 C-0.077 C^{2}+0.020 C^{3}
$$

このエネルギー係数 $\alpha$ を式 (12) に代入することによっ て, 体積濃度 $C$, 流量 $Q$, 水路幅 $B$ を与えて限界水深 $h_{c}$ を算出することができる.

限界水深が清水流の場合と異なる原因は, ダム頂地点 のエネルギー係数が異なる, すなわちダム頂での流速分 布が清水流の場合と異なることに因ると考えられる. 図 一11 から判るように濃度が $3.0 \%$ 以上では栓流域が存 在し, 濃度が $4.0 \%$ では限界水深の $10 \%$ が栓流域であ る. 幅広開水路等流の層流の場合の流速分布の理論式か 


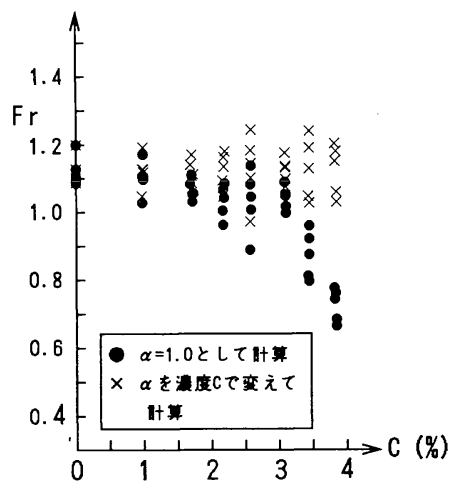

図-14 体積濃度 $C$ とダム頂地点のフルー ド数 $F_{r}$ の関係

らエネルギー係数を計算すると次式となり， $\tau_{f} / \tau_{0}$ の值 によって変化する.

$$
\alpha=\frac{27}{35} \frac{16+19 \tau_{f} / \tau_{0}}{\left(2+\tau_{f} / \tau_{0}\right)^{3}}
$$

図一14に体積濃度 $C$ とダム頂地点のフルード数 $F_{r}$ の関係を示す. は式（6）において $\alpha=1$ として計算 した值， $\times$ は図一13の各体積濃度 $C$ のエネルギー係数 $\alpha$ の值を式 (13) より求めて式 (6) に代入して計算し た値である.この図から, 濃度が大きい場合, エネルギー 係数を 1 として計算したダム頂地点のフルード数の值は 1 よりもかなり小さな值をとる. しかし, 各濃度により 算定したエネルギー係数 $\alpha$ を用いると, フルード数 $F_{r}$ は当然のことながら 1 に近い值になる.

\section{4. 結 論}

本研究では, 長方形断面開水路においてビンガム流体 とみなせる水とベントナイトの混合流体を用いて不等流 実験を行い，ダム越流による流れおよび跳水が混合流体 の濃度によってよ゙のように変化するかを調べ以下の結論 を得た。

1）本実験において跳水が発生した 0.0 2.6\%の濃度 の範囲 $\left(\tau_{f}<0.38 \mathrm{~Pa}, \eta_{p l}<23 \mathrm{mPa} \cdot \mathrm{s}\right.$ の範囲) に対して, 濃度の変化によらず実験值は従来の水平な長方形断面水
路における跳水に関する公式をほぼ満足した.

2）体積濃度 $C$ が $2.6 \%$ 以下ではダム頂地点まではほ とんよ゙エネルギ一損失がなかったのに，濃度が約 $3.0 \%$ を越えると（ダム頂地点の壁面せん断応力 $\tau_{0}$ に対する 降伏応力 $\tau_{f}$ の比が約 0.025 よりも大きくなる）限界水 深 $h_{c}$ の約 $50 \%$ のエネルギーが失われる.

3）ダム付近の栓流の様子を調べた結果，ダム頂地点の 栓流厚は濃度が約 $4.0 \%\left(\tau_{f}=19 \mathrm{~Pa}, \eta_{p l}=364 \mathrm{mPa} \cdot \mathrm{s}\right)$ で限界水深の $10 \%$ 程度であり, 濃度が 3.0 以下 $\left(\tau_{f}\right.$ $\left.<1.2 \mathrm{~Pa}, \eta_{p l}<46 \mathrm{mPa} \cdot \mathrm{s}\right)$ では栓流の厚さを無視する ことが出来る.

4）体積濃度が約 $3.0 \%$ を越えると（ダム頂で $\tau_{f} / \tau_{0}>$ $0.025)$ ，限界水深は急激に大きくなる．これは栓流が発 生して流速分布が急変し, エネルギー補正係数 $\alpha$ が 1.0 より大きくなることが原因と考えられる．ここでは濃度 $C$ の変化に対応する限界水深算出の実験式（式 (13)) を定めた。

終わりに本研究の遂行のために多大な協力を頂いた山 梨大学の当時の大学院生三浦美香氏はじめ卒論生に謝意 を表す。

\section{参 考 文 献}

1) 高橋 保: 土石流の発生と流動に関する研究, 京都大学 防災研究所年報, 第 20 号 B-2, pp. 405 435, 1977.

2）谷口義信 : 土石流の基礎的研究一主として泥しょう流の 流動学的解析一, 宮崎大学農学部演習林報告, 第 7 号, pp. $1 \sim 85,1974$.

3）山岡 勲 (代表)：火山灰・軽石の集合流動（泥流）の発 生領域と防災計画に関する研究—流路工内を流れる泥流 の平均流速に関する実験一, 昭和 $54 \cdot 55$ 年度文部省科学 研究費補助金試験研究成果報告書, pp. 1 34, 1981.

4) Hao, Z. and Zenghai, R. : Resistance test of Bingham's hyperconcentration fluid in rectangular open channel, Kexue Tongbao, Vol.27, No.7, pp.748 753, 1982.

5) Ogihara, Y. and Miyazawa, N. : Laws of resistance of pipe flow of solid-liquid mixtures, J. Hydraul. Res., Vol.29, No.2, pp.189 205, 1991.

6) Chow, V.T.(石原籐次郎訳) : 開水路の水理学 II, 丸善, pp. 363 368, 1962 年.

(1993. 3.29 受付)

\section{HYDRAULIC CHARACTERISTICS OF FLOW OVER DAM AND HYDRAULIC JUMP OF BINGHAM FLUID}

Yoshio OGIHARA and Naoki MIYAZAWA

In this paper, the experiments of varied flow in a rectangular open channel were carried out using the mixtures of water and bentonite which were regarded as the Bingham fluid and the manner in which the flow over a dam and the hydraulic jump were varied by concentration of the mixtures. As a result, it was shown that experimental results to mixtures with volumetric concentration less than $2.6 \%$ (yield stress $\tau_{f}<0.38 \mathrm{~Pa}$, plastic viscosity $\eta_{p l}<23 \mathrm{mPa} \cdot \mathrm{s}$ ) satisfied the existing formulas regarding the hydraulic jump. And it was shown that when the concentraion was over $3.0 \%\left(\tau_{f}>1.2 \mathrm{~Pa}, \eta_{p l}>46 \mathrm{mPa} \cdot \mathrm{s}\right)$, the critical depth increased dramatically, and about $10 \%$ of the critical depth was the depth of plug flow at concentration $4.0 \%\left(\tau_{f}=19 \mathrm{~Pa}, \eta_{p l}=364 \mathrm{mPa} \cdot \mathrm{s}\right)$. 